\title{
ANALISIS IMPLEMENTASI PROGRAM DETEKSI DINI KANKER SERVIKS DENGAN METODE INSPEKSI VISUAL ASAM ASETAT (IVA)
}

\section{ANALYSIS OF EARLY DETECTION PROGRAM OF CERVICAL CANCER IMPLEMENTATION WITH VISUAL INSPECTION ACETIC ACID (VIA)}

\author{
Inda Shopia Benita ${ }^{1 *}$, Siti Saadah Mardiah, Nita Nurvita ${ }^{3}$ \\ ${ }^{1}$ Politeknik Kesehatan Kemenkes Tasikmalaya \\ email : indashopiabenita.311112117@gmail.com
}

\begin{abstract}
ABSTRAK
Program deteksi kanker serviks melalui pemeriksaan IVA sudah diberlakukan di seluruh puskesmas di Indonesia sejak tahun 2010 dan menargetkan 10\% dari WUS setiap tahunnya. Kota Tasikmalaya memiliki cakupan 6,41\% di Tahun 2018. Tujuan penelitian ini untuk mengetahui implementasi program deteksi dini kanker serviks dengan metode Inspeksi Visual Asam Asetat (IVA) di Puskesmas Kota Tasikmalaya.

Penelitian ini menggunakan metode kualitatif dengan rancangan deskriptif. Pengumpulan data dilakukan dengan menggunakan wawancara mendalam berdasarkan kriteria purposive sampling dari Puskesmas yang mengalami peningkatan dan penurunan dalam pelaksanaan IVA. Subjek penelitian adalah Bidan, dokter dan Pemegang Program PTM sebagai informan utama dan untuk triangulasi informan adalah 2 Pemegang Program Penyakit Tidak Menular (P2PTM) di Dinas Kesehatan Kota Tasikmalaya, 7 kepala puskesmas, 7 kader dan 7 wanita usia reproduksi. Hasil penelitian menunjukkan bahwa implementasi program deteksi dini kanker serviks dengan metode IVA di Puskesmas Kota Tasikmalaya masih memiliki beberapa kendala dalam sosialisasi program, sehingga tenaga kesehatan dan wanita usia reproduksi masih belum memiliki pemahaman yang baik tentang informasi program serta minimnya SDM terlatih dan ketersediaan IVA kit di setiap Puskesmas, hal tersebut dipengaruhi oleh komunikasi, sumber daya, dan disposisi. Perlu adanya peningkatan sosialisasi program baik dari Dinas Kesehatan Kota Tasikmalaya maupun dari puskesmas.
\end{abstract}

Kata Kunci : Implementasi, Program deteksi dini kanker serviks, Inspeksi Visual Asam Asetat (IVA). 


\begin{abstract}
Early detection of cervical cancer using Acetic Acid Visual Inspection has been done at all main health centers in Indonesian since 2010 . The target is $10 \%$ of women of childbearing age each year. The City of Tasikmalaya has a coverage of $6.41 \%$ in year 2018. The research's aim is to analyze the implementation of Acetic Acid Visual Inspection program at health centers in Tasikmalaya City. This research used a qualitative method with descriptive design. The data collection was done using indepth interview based on purposive sampling criteria of the primary healthcare center that had increase and decrease in VIA. The research subjects were midwives, doctors and PTM Program Holders as the main informant and for the triangulations informants were 2 head of infectious diseases unit in Tasikmalaya District Health Office, 7 head of primary healthcare center, 7 cadres, and 7 women of reproductive age. The results showed that the implementation of Acetic Acid Visual Inspection program at health centers in Tasikmalaya City still had some constraint in program socialization, so that health workers and women of reproductive age still had not have good understanding of program information and the lack of trained HR and the availability of VIA kits in for each Health Center, this is influenced by communication, resources, and disposition. It needs to be an increase in program socialization from the Tasikmalaya City Health Office and from the health center
\end{abstract}

\title{
Key words: Implementation, cervical cancer screening program, visual inspection with acetic acid (VIA).
}

\section{PENDAHULUAN}

Kanker tertinggi di Indonesia pada perempuan adalah kanker payudara dan kanker leher rahim. Berdasarkan estimasi data Global Cancer Observatory (GLOBOCAN), International Agency for Research on Cancer (IARC) (2018), kasus kanker serviks di Indonesia mencapai angka 32.469 jiwa. Angka kematian akibat kanker serviks mencapai 18.279 jiwa pertahun, ini artinya sekitar 50 perempuan Indonesia meninggal dunia akibat kanker serviks. ${ }^{2}$

Prevalensi penderita kanker serviks di Jawa Barat sendiri berdasarkan Prevalensi kanker serviks RSUP dr Hasan Sadikin Bandung pada tahun 2018, mencapai 0,0118\%. Sepanjang tahun 2017 RSHS telah merawat pasien 4.694 penderita kanker serviks (pasien baru dan lama) dan pada tahun 2018 terdiagnosa kanker serviks terjadi 
penurunan sebanyak 904 dari jumlah wanita di Jawa Barat 21.146.692. Peningkatan jumlah pasien yang terdeteksi menderita kanker serviks juga disebabkan oleh meningkatnya cakupan program deteksi kanker serviks di berbagai daerah di Jawa Barat dan edukasi mengenai kanker serviks di masyarakat. ${ }^{3}$

Tingginya angka kematian akibat kanker serviks disebabkan karena rendahnya kesadaran perempuan melakukan deteksi dini dan sebagian besar pasien kanker serviks datang ke rumah sakit sudah dalam stadium lanjut. Kanker serviks dapat dicegah, dengan mendeteksi sedini mungkin lesi pra kanker, maka dapat segera dilakukan penanganan dan kanker serviks dapat dicegah. Pemerintah telah melaksanakan program deteksi dini kanker serviks dalam mengendalikan kanker serviks dengan menggunakan metode (IVA) Inspeksi Visual Asam Asetat. ${ }^{1}$

Data dari Sub Direktorat Pengendalian Penyakit Kanker Direktorat Pengendalian Penyakit Tidak Menular Kemenkes RI, dari tahun 2014 sampai dengan tahun 2018 program deteksi dini kanker serviks dengan menggunakan metode IVA telah berjalan pada 1.986 Puskesmas di 304 Kabupaten atau Kota yang berada di 34 Provinsi di Indonesia. Cakupan hasil kegiatan dari tahun 2014 sampai 2018, yaitu telah dilakukan skrining terhadap 37.415 .483 orang (7,34\%) dengan hasil IVA positif sebanyak 77.969 orang dan suspek kanker serviks sebanyak 3.563 orang (1,2 per 1.000 orang). Berdasarkan data tersebut dapat dilihat masih rendahnya pelaksanaan deteksi dini yaitu kurang dari 10\%, sedangkan target yang harus dicapai pada tahun 2019 adalah 80\%. ${ }^{5}$ Di Provinsi Jawa Barat pada tahun 2018, jumlah perempuan yang telah dilakukan skrining kanker serviks dengan metode IVA berjumlah 206.775 orang (3,02\%) dengan hasil IVA positif sebanyak 4.183 orang dan suspek kanker serviks sebanyak 263 orang. $^{5}$

Kota Tasikmalaya memiliki 21 Puskesmas namun hanya 16 Puskesmas yang telah melaksanakan program deteksi dini kanker serviks dengan metode IVA. Data tahun 2018 Kota Tasikmalaya memiliki 102.091 wanita yang berusia 30-50 tahun, namun hanya 6.542 atau sebesar 6,41\% wanita yang telah melakukan deteksi dini kanker serviks dengan metode IVA dan 9 diantaranya dinyatakan suspek kanker serviks dan 101 orang di nyatakan IVA positif. ${ }^{6}$

Berdasarkan data cakupan deteksi dini kanker serviks tahun 2018 di Wilayah Kota Tasikmalaya Puskesmas "K" merupakan Puskesmas dengan cakupan tertinggi sebanyak 1.818 orang dari 3.933 WUS usia 30-50 tahun, sedangkan dengan jumlah WUS terbanyak namun cakupan pemeriksaan IVA tes masih rendah terdapat di Puskesmas "P" yaitu 6 orang yang melakukan pemeriksaan IVA tes dari jumlah WUS 10.950 orang, adapun lima Puskesmas yang tidak melaksanakan program deteksi dini kanker leher rahim, yaitu Puskesmas "KA", Puskesmas "C", Puskesmas " $P$ ", Puskesmas "S", dan Puskesmas "S". 6 
Berdasarkan studi pendahuluan yang dilakukan pada bulan Oktober tahun 2019 kepada petugas Puskesmas yang tidak melaksanakan program deteksi dini kanker serviks dengan metode IVA dan salah satu petugas pemegang program penyakit tidak menular (P2PTM) di Dinas Kesehatan Kota Tasikmalaya, bahwa pelaksanaan program deteksi dini kanker serviks belum dilakukan secara optimal, karena baru disosialisasikan dan akan dilakukan secara keseluruhan di puskesmas pada tahun 2020, hal tersebut disebabkan minimnya tenaga kesehatan yang mendapatkan pelatihan, namun untuk sarana dan prasarana sudah tersedia. Metode pemeriksaan disesuaikan dengan Standar Operasional Prosedur, kerangka acuan kerja pemeriksaan IVA, dan atlas IVA. ${ }^{6}$

Berdasarkan hasil wawancara kepada petugas Puskesmas yang tidak melaksanakan program deteksi dini kanker serviks dengan metode IVA tersebut bahwa pelaksanaan deteksi dini dengan metode IVA belum berjalan dengan baik, Puskesmas tidak menetapkan jumlah target dari jumlah populasi WUS yang seharusnya dilakukan pemeriksaan IVA dalam kurun waktu yang ditentukan. Puskesmas juga tidak menentukan jadwal tetap untuk pemeriksaan IVA sehingga WUS yang ingin melakukan pemeriksaan IVA, sehingga harus menunggu jadwal dari Puskesmas untuk melakukan pemeriksaaan. ${ }^{6}$

Menurut George C. Edwards III dalam Widodo (2014), terdapat empat variabel yang menentukan keberhasilan suatu kebijakan, yaitu komunikasi (communications), sumber daya (resources), sikap (dispositions atau attitudes) dan struktur birokrasi (bureutic structure). ${ }^{19}$ Variabel variabel inilah yang dapat mempengaruhi suatu kebijakan dalam rangka mencapai tujuannya. Keempat variabel diatas dalam model yang dibangun oleh Edward memiliki keterkaitan dengan satu yang lain dalam studi mengenai implementasi kebijakan. Keempat variabel ini saling berhubungan serta mempengaruhi satu sama lain dalam proses mencapai suatu kebijakan. Berdasarkan uraian permasalahan tersebut dan pentingnya pelaksanaan program deteksi dini kanker serviks metode IVA maka peneliti tertarik untuk mengetahui sejauh mana pelaksanaan program deteksi dini kanker serviks melalui metode IVA di Puskesmas Kota Tasikmalaya.

\section{METODE PENELITIAN}

Jenis penelitian kualitatif dengan menggunakan pendekatan deskriptif melalui wawancara mendalam (indepth interview) terhadap informan utama dan triangulasi terkait implementasi program deteksi dini kanker serviks melalui metode IVA di Puskesmas Kota Tasikmalaya. Kriteria purposiv penelitian ini adalah puskesmas yang melaksanakan program deteksi dini kanker serviks melalui metode IVA di wilayahnya dan mengalami peningkatan serta penurunan cakupan pemeriksaan IVA pada tahun 
2018. Berdasarkan kriteria purposiv tersebut terpilih sebanyak 7 puskesmas yaitu Puskesmas "K", Puskesmas "P", Puskesmas "KA", Puskesmas "C", Puskesmas "P", Puskesmas "S", dan Puskesmas "S".

Instrumen utama pengumpulan data pada penelitian kualitatif ini adalah peneliti sendiri. Penelitian yang menitik beratkan pada pendekatan kualitatif ini menggunakan metode pengumpulan data dengan wawancara mendalam (indepth interview) sehingga data yang didapat adalah data primer. Indepth interview merupakan suatu cara pengumpulan data atau informasi dengan cara langsung bertatapan dengan informan dengan maksud mendapatkan gambaran lengkap tentang topik yang diteliti. ${ }^{20}$

Keabsahan data dicapai melalui derajat kepercayaan (credibility) dengan teknik triangulasi yaitu triangulasi sumber dan metode. Triangulasi merupakan teknik pemeriksaan keabsahan data yang memanfaatkan sesuatu yang lain. Analisa data pada penelitian ini mengadopsi model Miles dan Huberman (1992) dalam Sugiyono (2017) yang terdiri dari tiga kegiatan yaitu penyederhanaan/reduksi data, penyajian data, penarikan kesimpulan dan verifikasi. ${ }^{21}$

\section{HASIL PENELITIAN DAN PEMBAHASAN}

Program deteksi dini kanker serviks melalui metode IVA di Kota Tasikmalaya telah dilaksanakan kurang lebih dua tahun yaitu sejak tahun 2017. Program ini telah dilaksanakan di 16 Puskesmas dari 21 total Puskesmas di Kota Tasikmalaya. Sasaran program adalah WUS usia 30-50 tahun.

Terdapat perbedaan hambatan dan upaya yang dilakukan oleh Puskesmas dengan cakupan tinggi atau Puskesmas yang memiliki cakupan rendah dalam pemeriksaan IVA. Perbedaan tersebut ditunjukan dalam implementasi kegiatan promosi dan edukasi melalui sosialisasi program. Puskesmas dengan cakupan tinggi cenderung memiliki upaya lebih dibandingkan puskesmas dengan cakupan rendah, diwujudkan dengan cara memberdayakan kader untuk aktif dalam sosialiasasi program deteksi dini kanker serviks melalui metode IVA dan menjalin kerja sama antara bidan pelaksana dengan lintas program dan lintas sektoral, serta konseling pada setiap pasien yang berpengaruh besar terhadap indikator program deteksi dini kanker serviks yaitu cakupan pemeriksaan IVA.

Puskesmas dengan cakupan lebih rendah belum optimal dalam upaya promosi dan edukasi melalui sosialisasi. Hal tersebut dipengaruhi kurangnya komunikasi dalam kejelasan (clarity) dan penyampaian tentang target dan sasaran dalam program ini, yang terjalin antara bidan pelaksana dengan kepala puskesmas maupun pemegang program PTM dan Dinas Kesehatan, sehingga bidan merasa kurang mendapat dukungan dan dorongan lebih untuk menjalankan program. 
Kurang optimalnya pelaksanaan implementasi program deteksi dini kanker serviks dengan metode IVA di Puskesmas Kota Tasikmalaya juga dipengaruhi oleh sumber daya manusia dan sarana prasarana, Puskesmas dengan cakupan tinggi memiliki 2 bidan, 1 perawat dan 1 dokter yang telah mendapatkan pelatihan IVA juga dokter yang telah mendapatkan pelatihan krioterapi. Puskesmas dengan cakupan rendah dalam pemeriksaan IVA hanya memiliki 1 bidan dan 1 dokter yang mendapatkan pelatihan IVA, serta tidak adanya ketersedian IVA Kit di setiap Puskesmas sehingga masih bergantung dengan IVA Kit, hal tersebut menjadi faktor penghambat dalam implementasi program deteksi dini kanker serviks.

Komunikasi dan disposisi (sikap) dalam pelaksanaan program deteksi dini kanker serviks di Wilayah Puskesmas Kota Tasikmalaya merupakan faktor pendukung dari berjalannya program, hal tersebut dibuktikan berdasarkan hasil wawancara Puskesmas dengan cakupan tertinggi lebih berkomitmen untuk menjalankan program melalui sosialisasi dan kerja sama dengan lintas program dan lintas sektor, namun perlu adanya dukungan logistik dari Dinas Kesehatan Kota Tasikmalaya.

Puskesmas dengan cakupan rendah dalam pelaksanaan IVA menunjukkan sikap dan komitmen mengesampingkan program deteksi dini kanker serviks, karena bukan salah satu program di puskesmas yang menjadi fokus utama, sehingga belum ada komitmen untuk menjalankan program secara terjadwal, serta tidak adanya tuntutan dari dinas untuk target dan sasaran IVA, sikap dari petugas kesehatan sendiri pun masih ada yang enggan untuk memeriksakan IVA karena merupakan hal yang sangat sensitiv, pengawasan dan pencatatan pelaporan tidak ada khusus untuk IVA namun keseluruhan Program PTM baik oleh kepala puskesmas maupun dari Dinas Kesehatan Kota Tasikmalaya, setelah ada pelatihan IVA di bulan Oktober 2019 di Poltekkes Tasikmalaya, mulai ada komitmen untuk menjalankan program dengan pembuatan RUK 2020, hal tersebut menunjukkan perlu adanya dukungan dari Dinas Kesehatan Kota Tasikmalaya terkait peraturan dan target sasaran.

Berdasarkan hambatan dalam komunikasi dijelasakan dalam Peraturan Menteri Kesehatan Republik Indonesia Nomor 43 Tahun 2016 tentang Standar Pelayanan Minimal Bidang Kesehatan pada indikator No. 6 tentang pelayanan kesehatan pada usia produktif, bahwa skrining pada Usia 30-50 tahun wajib dilakukan dalam 1 tahun sekali, namun transmisi dan clarity sosialisasi peraturan tersebut baik dari dinas kesehatan maupun puskesmas belum optimal dilakukan. Hal tersebut mempengaruhi berjalannya implementasi program sesuai dengan teori George Edward C mengatakan bahwa variabel komunikasi terdiri dari transmission (penyampaian informasi), clarity (kejelasan), dan consistency (konsisten), hal tersebut sangat menentukan keberhasilan pencapaian tujuan dari implementasi kebijakan 
publik. Implementasi akan berhasil apabila para pembuat keputusan (decision maker) sudah mengetahui apa yang akan dikerjakan. ${ }^{19}$

Faktor sumber daya dalam implementasi program deteksi dini kanker serviks pun sangat mempengaruhi, minimnya sumber daya manusia (bidan, dokter) yang terlatih serta tidak adanya IVA Kit mempengaruhi berjalannya program. Berdasarkan Peraturan Menteri Kesehatan Republik Indonesia Nomor 29 Tahun 2017 Tentang Perubahan Atas Peraturan Menteri Kesehatan Nomor 34 Tahun 2015 tentang Penanggulangan Kanker Payudara Dan Kanker Leher Rahim bahwa kebutuhan SDM untuk melakukan pemeriksaan IVA, dapat dilakukan oleh bidan terlatih atau dokter umum terlatih. Jumlah yang diharapkan ada 2 (dua) orang bidan terlatih dan 1 (satu) orang dokter umum terlatih dalam tiap Puskesmas. ${ }^{28}$ IVA KIT sendiri dalam Peraturan Menteri Kesehatan Republik Indonesia Nomor 43 Tahun 2016 tentang Standar Pelayanan Minimal Bidang Kesehatan dalam indikator ke-6 tentang Pelayanan Kesehatan Usia Produktif seharusnya disediakan alat tersendiri untuk IVA KIT. ${ }^{31} 32$

Adanya perbedaan disposisi atau sikap dalam komitmen pada pelaksanaan IVA tes di Puskesmas Kota Tasikmalaya antara puskesmas dengan cakupan tertinggi dan puskesmas dengan cakupan rendah, dipengaruhi karena kurangnya komunikasi antar lintas program maupun dengan Dinas Kesehatan.

Menurut teori George C. Edward III, keberhasilan atau kegagalan suatu implementasi dapat dipengaruhi oleh variabel sikap dan komitmen bidan selaku pelaksana IVA dan komunikasi memiliki pengaruh besar dalam hal kaitannya dengan implementasi promosi dan edukasi melalui media dan sosialisasi. Ketika seorang implementor memiliki sikap atau perspektif yang berbeda dengan pembuat kebijakan, maka proses implementasi kebijakan juga menjadi tidak efektif. ${ }^{19}$

Variabel disposisi ini dipengaruhi oleh variabel komunikasi. Jika proses komunikasi berjalan baik dan lancar tentu akan memberikan sikap dan motivasi yang baik bagi bidan. Kurangnya komunikasi yang terjalin antara bidan pelaksana dengan kepala puskesmas maupun PTM dan Dinas Kesehatan membuat bidan merasa kurang mendapat dukungan dan dorongan lebih untuk menjalankan program. ${ }^{19}$

Hal tersebut sesuai dengan teori George Edward C III mengatakan bahwa, jika implementasi kebijakan ingin berhasil secara efektif dan efisien, para pelaksana (implementors) tidak hanya mengetahui apa yang harus dilakukan dan mempunyai kemampuan untuk melakukan kebijakan tersebut, tetapi mereka juga harus mempunyai kemauan untuk melaksanakan kebijakan tersebut. ${ }^{19}$

Adanya solusi dalam meningkatkan cakupan pelaksanaan IVA yang dilakukan oleh setiap Puskesmas dan Dinas Kesehatan sesuai dengan Peraturan Menteri Kesehatan Republik Indonesia Nomor 29 Tahun 2017 Tentang Perubahan Atas Peraturan Menteri Kesehatan Nomor 34 Tahun 2015 tentang Penanggulangan 
Kanker Payudara dan Kanker Leher Rahim, pasal 15 menjelaskan bahwa Agar skrining dapat dilaksanakan dengan baik dan mencapai tujuan yang diinginkan. ${ }^{31} 32$

\section{SIMPULAN}

Implementasi program deteksi dini kanker serviks melalui metode IVA di Kota Tasikmalaya masih belum optimal. Berdasarkan pembahasan hasil penelitian tentang implementasi program deteksi dini kanker serviks melalui metode IVA di puskesmas Kota Tasikmalaya, dapat disimpulkan pada kegiatan promosi dan edukasi melalui media dan sosialisasi program deteksi dini kanker serviks melalui metode IVA serta konseling belum berjalan optimal, karena kurangnya sosialisasi Peraturan Menteri Kesehatan Republik Indonesia Nomor 4 Tahun 2019 tentang Standar Teknis Pemenuhan Mutu Pelayanan Dasar Pada Standar Pelayanan Minimal Bidang Kesehatan.

Hambatan sumber daya manusia, sarana dan prasarana dalam pelaksanaan program deteksi dini kanker servik adalah masih minimnya bidan dan dokter yang telah mendapatkan pelatihan di setiap Puskesmas, serta kurangnya IVA Kit sesuai Peraturan Menteri Kesehatan Republik Indonesia Nomor 4 Tahun 2019 Tentang Standar Teknis Pemenuhan Mutu Pelayanan Dasar Pada Standar Pelayanan Minimal Bidang Kesehatan.

Hambatan pada Disposisi atau sikap yaitu rendahnya motivasi dan komitmen bidan yang dipengaruhi oleh kurang baiknya komunikasi yang terjalin antara bidan pelaksana, kepala puskesmas, PTM, dan Dinas kesehatan Kota Tasikmalaya. Para implementor bersikap baik terhadap suatu kebijakan tertentu, jika adanya dukungan atau kejelasan dari peraturan kebijakan, kemungkinan besar mereka melaksanakan kebijakan sebagaimana yang diinginkan oleh pembuat kebijakan sesuai Peraturan Menteri Kesehatan Republik Indonesia Nomor 4 Tahun 2019 Tentang Standar Teknis Pemenuhan Mutu Pelayanan Dasar Pada Standar Pelayanan Minimal Bidang Kesehatan.

Dinas Kesehatan Kota Tasikmalaya sebaiknya melaksanakan kegiatan pertemuan dan sosialisasi program deteksi dini kanker serviks melalui metode IVA dengan bidan pelaksana maupun pemegang program PTM secara rutin dan mengevaluasi ketersediaan tenaga IVA terlatih di puskesmas Kota Tasikmalaya.

Bagi Bidan dan Pemegang Program Penyakit Tidak Menular (P2PTM) perlu meningkatkan perannya dalam pelaksanaan program deteksi dini kanker servik dengan metode IVA seperti melakukan sosialisasi dan penyuluhan serta melakukan kerjasama dengan pihak-pihak yang berpengaruh di lingkungan sekitar. selanjutnya dapat mengadakan rapat koordinasi serta monitoring evaluasi antara bidan 
pelaksana, pemegang program PTM, dan kepala puskesmas, serta lintas sektor secara rutin.

\section{DAFTAR PUSTAKA}

1. Kemenkes. Buletin Kanker. Jakarta: Pusat Data dan Informasi Kementerian Kesehatan Republik Indonesia, 2015. hal. 10-40. [Diunduh 1 Oktober 2019]. Tersedia di www.depkes.go.id

2. Globocan. (Estimated Cancer Incidence, Mortality,Prevalence and Disabilityadjusted life years DALYs on Worldwide. s.l.: IARC Cancer, 2018. [Diunduh 1 Oktober 2019]. Tersedia dari http://gco.iarc.fr/

3. RSHS. Laporan Akuntabilitas Kinerja RSUP DR. Hasan Sadikin Bandung Tahun 2018. Bandung: RSUP Dr. Hasan Sadikin Bandung, 2018. hal. 28. [Diunduh 1 Oktober 2019]. Tersedia dari http: https://e-renggar.kemkes.go.id/

4. Kemenkes. Profil Kesehatan indonesia. Jakarta: Kementerian Kesehatan Republik Indonesia, 2018. [Diunduh 1 Oktober 2019]. Tersedia di www.depkes.go.id

5. Dinas Kesehatan Kota Tasikmalaya. Profil Kesehatan Kota Tasikmalaya. Tasikmalaya : Dinas Kota Tasikmalaya, 2018.

6. Kemenkes. Rencana Strategis Kementerian Kesehatan Tahun 2015-2019. Jakarta: Kemenkes, 2015. Keputusan Menteri Kesehatan Republik Indonesia HK02.02/Menkes/42/2015. hal. 1-120.

7. Maghfiro, Ilmia Nur, dkk. Implementasi Program Tes Visual Asam Acetat (IVA) Tes di Puskesmas Sukoharjo. Surakarta: Universitas Muhammadiyah Surakarta, 2018, University Research Colluqulum, hal. 40-45. [Diunduh 1 Oktober 2019]. Tersedia http://repository .urecol.org/

8. Bustan, M. 2007. Epidemiologi Penyakit Tidak Menular. dalam Helena, Armianti. Implementasi Program Deteksi Dini Kanker Serviks dengan Metode IVA Tes di Puskesmas Medan Sunggal. Medan: Universitas Sumatra Utara, 2018, hal. 1445. 
9. Wulandari. (2010). Pengertian dan Pemahaman Resiko Ca Cerviks Pada Wanita Usia Subur di Indonesia (Vol. 2). Jakarta: Rineka Cipta.

10. Prawirohardjo, S. (2014). Ilmu Kandungan . Jakarta: PT. Bina Pustaka Sarwono Prawirohardjo.

11. Winarni, Sri Kustiyati. Deteksi Dini Kanker Leher Rahim dengan Metode IVA Tes di Wilayah Kerja Puskesmas Ngoresan Surakarta. 2016, GASTER, hal. 681-694. [Diunduh 1 Oktober 2019]. Tersedia https://www.jurnal.stikes-aisyiyah.ac.id

12. FIGO Committee On Gynecologic Oncology. 2009. Staging Classifications and Clinical Practice of Gynelogic Cancers. dalam Kemenkes. Panduan Penatalaksanaan Kanker Serviks. Jakarta: Komite Penanggulangan Kanker Nasional, 2014, hal. 1-44.

13. Rasjidi,Iman. (2017). 100 Questions and Answer Kanker Pada Wanita. Jakarta: PT. Elex Media Komputido.

14. American Cancer Society. (2016). What is Cervical Cancer. America: American Cancer Society.

15. Dianada, Rama. (2018). Mengenal Seluk Beluk Kanker. Yogyagkarta: Kata Hati.

16. Tim Cancer Help. (2017). Stop Kanker: Panduan Deteksi Dini dan Pengobatan Menyeluruh Berbagai Jenis Kanker. Jakarta: Agro Media Pustaka.

17. Kemenkes. (2014). Panduan Penatalaksanaan Kanker Serviks. Jakarta: Komite Penanggulangan Kanker Nasional.

18. WHO. (2017). Comprehensive Cervical Cancer Contol a Guide to Essential Practice. Dalam E. Moegeni, Pencegahan Kanker Serviks Terpadu di Indonesia (hal. 77-100). Jakarta: Fakultas Kedokteran Universitas Indonesia.

19. George C. Edward. (2014). Implementing Public Police. Dalam J. Widodo, Analisis Kebijakan Publik (hal. 135-144). Malang: Bayu Media.

20. Moleong. (2016). Metodologi Penelitian Kualitatif (22 ed.). Bandung: Rosda Karya. 
21. Sugiyono. (2017). Metode Penelitian Kuantitatif, Kualitatif, dan R\&D. Bandung: Alfabeta.

22. Notoatmodjo, S. (2014). Pendidikan dan Perilaku Kesehatan. Jakarta: Rineka cipta.

23. Miles, B. Mathew dan Michael Huberman . (2017). Analisis data Kualitatif. Dalam Sugiyono, Metode Penelitian Kuantitatif, Kualitatif, dan R\&D (hal. 79). Bandung: Alfabeta.

24. Kepmenkes RI. Kepmenkes RI Nomor 796/MENKES/SK/VII/2010 tentang Pedoman Kanker Payudara dan Kanker Leher Rahim. Kemenkes RI. Jakarta; 2010

25. Kepmenkes RI. Peraturan Menteri Kesehatan Republik Indonesia Nomor 29 Tahun 2017 tentang Penanggulangan Kanker Payudara dan Kanker Leher Rahim. Kemenkes RI. Jakarta; 2010

26. Saraswati, Meytri; Ayun Sriatmi; Sutopo Patria Jati. 2017. Analisis Implementasi Program Deteksi Dini Kanker Serviks Melalui Metode Inspeksi Visual Asam Asetat (Iva) Di Puskesmas Kota Semarang. semarang: Jurnal Kesehatan Masyarakat, 2017, e-journal, Vol. 5. hal. 85-92. ISSN: 2356-3346. [diunduh pada tanggal 2 Oktober 2019]. Tersedia journal.undip.ac.id

27. Apriningrum, Nelly. dkk. 2017. Evaluasi Input Pada Program Pencegahan Kanker Serviks Dengan Pemeriksaan Iva Di Kabupaten Karawang. Karawang: Midwife Journal, 2017, Vol. 3. hal. 53-64. pISSN 2477-3441/elSSN 2477-345X. [diunduh pada tanggal 2 Oktober 2019]. Tersedia e-journal.undip.ac.id

28. Edriyani, Agustin; Djawardi Dasuki;Retno Mawarti. 2017. Analisis Program Skrining kanker Serviks di Sleman DIY;Studi Kualitatif.. Sleman : Jurnal kebidanan dan Keperawatan, 2017, Vol. 13, hal. 95-103. ISSN: 2477-8184. [diunduh pada tanggal 2 Oktober 2019]. Tersedia journal.unisayogya.ac.id

29. Ernawati, Astrid Novita. 2017. Alternatif Kebijakan Operasional Program Skrining Kanker Serviks di Kabupaten Garut Tahun 2017. Garut: Journal Unsika, 2017, Vol. 3. Hal 91-105. ISSN: 2477-7174. [diunduh pada tanggal 2 Oktober 2019]. Tersedia https://journal. unsika.ac.id/ 
Asian Research Midwifery and Basic Science Journal e-ISSN:

30. Badan Pusat Statistik Kota Tasikmalaya. 2018. Statistik Kota Tasikmalaya Tahun 2018. Tasikmalaya: Badan Pusat Statistik Kota Tasikmalaya, 2018. [diunduh pada tanggal 20 Desember 2019]. Tersedia https:WwW.tasikmalayakota.bps.go.id

37. Kepmenkes RI. Peraturan Menteri Kesehatan Republik Indonesia Nomor 43 Tahun 2016 Tentang Standar Pelayanan Minimal Bidang Kesehatan. Kemenkes RI. Jakarta; 2016

32. Kepmenkes RI. Peraturan Menteri Kesehatan Republik Indonesia Nomor 4 Tahun 2019 Tentang Standar Teknis Pemenuhan Mutu Pelayanan Dasar Pada Standar Pelayanan Minimal Bidang Kesehatan Kemenkes RI. Jakarta; 2019 